\title{
NUTRIPLEN Trade Mark Casenote
}

\author{
Dr Paul Lambert
}

Trade mark infringement; NUTRIPLETE; NUTRIPLEN; Article 9 ETMR; Article 102(1) ETMR; account of profits; no profits; damages; bad faith; notional licence fee; damages reduced in part as prior assignment lower than notional licence fee

This relates to a trade mark infringement decision in the in a case entitled Nutrimedical B.V. and by order Aymes International Limited v Nualtra Limited. The judgment of Mr. Justice Twomey, delivered on 2 May 2017, decides that the registered mark NUTRIPLETE was infringed by NUTRIPLEN, in particular likelihood of confusion. The claim was that the use by Nualtra Limited (Nualtra) of the mark NUTRIPLEN infringed the rights of the registered trade mark NUTRIPLETE. Ultimately, infringement was held, but damages were reduced.

\section{Background}

The proceedings were instituted against Nualtra by Nutrimedical B.V. (Nutrimedical), the original NUTRIPLEN trade mark owner, but continued by the assignee, Aymes International Limited (Aymes). The case was decided at the Irish High Court (commercial division). The core issue was infringement and Article 9 of the Trade Mark Regulation (ETMR). ${ }^{1}$ The Article 9 claim was that there was a likelihood of confusion on the part of the public between Nualtra's NUTRIPLEN mark and the NUTRIPLETE trade mark.

The key issue in the case was whether there was a likelihood of confusion on the part of the public between the registered trade mark NUTRIPLETE and the sign NUTRIPLEN. The judgment also considers

- $\quad$ the effect, if any, on that claim, of the conduct by the second-named plaintiff, which has been described by the High Court in earlier proceedings as "reprehensible";

- the consequences, if any, of the extraordinary fact that it can cost more to defend a claim than the claim is worth, since evidence was provided that it cost the defendant $€ 1.3$ million to defend a claim against it for damages of $€ 260,000$.

Nutrimedical, a Netherlands entity, manufactures medical nutritional supplements. NUTRIPLETE was registered by Nutrimedical as a CTM in 2012 in Classes 5 and 32, respectively for

"diatetic preparations adapted for medical use; Nutritional supplements for medical use; The aforesaid goods as tube feeding and liquid food; The aforesaid for medical supervision"

"mineral and soda water and other non-alcoholic beverages, fruit drinks and juices, syrups and other preparations for making beverages."

The defendant, Nualtra, began supplying and distributing oral nutritional supplements with NUTRIPLEN, NUTRIPLEN PROTEIN and NUTRIPLEN SMOOTHIE in 2012. These products, being oral nutrition supplements (ONS), can only be purchased under medical supervision, which means that they must either be purchased using a prescription, or if they are purchased without a

$1 \quad$ European Trade Mark Regulation 2015/2424 which amends Regulation 207/2009. 
prescription, they can only be purchased as an over the counter product (an "over the counter" product) from a pharmacy behind the dispensing counter.

Nualtra unsuccessfully applied to register NUTRIPLEN as a CTM also in Classes 5 and 32. OHIM decided that NUTRIPLEN was too similar to NUTRIPLETE, holding that there was a likelihood of confusion. A NUTRIPLEN appeal was out of time. The NUTRIPLEN PROTEIN and NUTRIPLEN SMOOTHIE appeals were rejected by the Board of Appeal.

Undertakings were sought from Nualtra not to use NUTRIPLEN and that it would withdraw products bearing the mark NUTRIPLEN within Classes 5 and 32. No undertakings were provided. The plaintiff had not launched any ONS products under the NUTRIPLETE range pending the undertakings.

Nualtra then commenced re-branding the NUTRIPLEN brand, partly resulting from infringement threats to its bottler/manufacturer, which led to it ceasing to supply Nualtra. By April 2016 Nualtra completed its re-branding under the name Altraplen in the UK, and by May 2016 in Ireland. No undertakings were given.

In the context of the failure by Nualtra to give the undertakings first requested on the 20 May7 2015, evidence was produced to the Court of the use of the NUTRIPLEN mark by Nualtra on its website on 21 September 2016, since there were a number of references on Nualtra's website to NUTRIPLEN. In particular, there was a reference to ordering NUTRIPLEN products, even though ONS products being sold by Nualtra at this time was being sold, since May 2016, under the Altraplen brand as a result of the re-branding that had occurred at that time.

Evidence was provided to the court that the British National Formulary is the journal of record for pharmacists and clinicians in the area of clinical nutrition and that it operates a website www.nutridrinks.co.uk, and that during the hearing, it still referred to ONS products under the NUTRIPLEN mark, a reference to "Nutriplen protein Strawberry (4 x 200ml) know as Altraplen".

\section{Behaviour}

Certain actions of Aymes were described by McGovern J. in an earlier hearing as "reprehensible". ${ }^{3}$ In July 2015 Aymes sent an anonymous letter to hundreds of UK GPs about Nutriplen products and about Nualtra. It made false and defamatory allegations about Nualtra e.g. that Nualtra did not have insurance, was not registered for data protection in the UK, that it only had an international telephone number on its products, etc. Aymes also sent an email purporting to emanate from the NHS, to NHS employees containing similar false and defamatory claims about Nualtra. Initially denied, these were eventually admitted. Nualtra received a settlement of $€ 101,000$ in respect of its counterclaim for damages for the defamation, plus costs.

The court noted that "[w]hile it is difficult to have any sympathy for a plaintiff such as Aymes, which has engaged in such reprehensible conduct, it is however crucial to realise that, as a result of the settlement of the defamation claim and the claim of unlawful interference with business, this Court's job is limited to dealing with the only remaining legal issue between the parties, namely whether, in the words of Article 9 of the [ETMR], there exists a likelihood of confusion on the part of the public between the signs NUTRIPLEN and NUTRIPLETE."

\section{Law}

Trade mark rights are set out in Article 9 of the ETMR which states that

"1. The registration of an EU trade mark shall confer on the proprietor exclusive rights therein.

Nutrimedical B.V. and by order Aymes International Limited v Nualtra Limited, parag 14.

See parag 4 of McGovern J.'s judgment in Nutrimedical B.V. and Aymes International Limited v Nualtra Limited [2016] IEHC 397. 
2. Without prejudice to the rights of proprietors acquired before the filing date or the priority date of the EU trade mark, the proprietor of the EU trade mark shall be entitled to prevent all third parties not having his consent from using in the course of trade, in relation to goods or services, any signs where:

[...]

(b) the sign is identical with, or similar to, the EU trade mark and is used in relation to goods or services which are identical with, or similar to, the goods or services for which the EU trade mark is registered, if there exists a likelihood of confusion on the part of the public; the likelihood of confusion includes likelihood of association between the sign and the trade mark". 4

Aymes, now the owner of the EU trade mark NUTRIPLETE, also relies on Article 102(1), in seeking an injunction

"Where a Community trade mark court finds that the defendant has infringed or threatened to infringe a Community trade mark, it shall unless there are special reasons for not doing so, issue an order prohibiting the defendant from proceeding with the acts which infringed or would infringe the Community trade mark. It shall also take such measures in accordance with its national law as are aimed at ensuring that this prohibition is complied with". 5

In Aldi Stores v Dunnes Stores, ${ }^{6}$ Cregan J. noted in relation to Article 102(1)

"It is clear therefore, having regard to the provisions of Article 102 (1) of the CTM, that where a Community Trade Mark Court finds that a defendant has infringed a Community trade mark it shall issue an order preventing the defendant from proceeding with the acts which infringed or would infringe the Community trade mark. There is therefore, under the Community trade mark regulation, an obligation on Community Trade Mark Courts to issue an injunction preventing further infringements of Community trade marks in the future, where a defendant has infringed a Community trade mark in the past.

Thus, the fact that the defendant's conduct has now ceased, does not appear to be a defence to an application for an injunction under the Community trade mark regulation (absent special reasons)."

The key issue for the Court was whether there is a likelihood of confusion between the marks. Relying on Cofresco v Controller of Patents, ${ }^{8}$ the Court summarised the legal principles applicable to an infringement

"(i) In determining the likelihood of confusion, account must be taken of all the circumstances of the case, including the degree of similarity between the two marks and between the goods or services, the likelihood that the public would make an association between the registered trade mark and the alleged infringing mark, and the distinctiveness of the registered trade mark.

(ii) In assessing the degree of similarity between two marks, the Court must determine the degree of visual, aural and conceptual similarity between them and, where appropriate, evaluate the importance to be attached to those different elements, taking account of the category of goods or services in question and the circumstances in which they are marketed. For this purpose the average consumer is deemed to be reasonably well-informed, reasonably observant and circumspect.

Nutrimedical B.V. and by order Aymes International Limited v Nualtra Limited, parag 19. Nutrimedical B.V. and by order Aymes International Limited v Nualtra Limited, parag 20. Aldi Stores v Dunnes Stores [2015] IEHC 551, parag 9.

Nutrimedical B.V. and by order Aymes International Limited v Nualtra Limited, parag 21. Cofresco v Controller of Patents [2007] 2 ILRM 430. 
(iii) The visual, aural, and conceptual similarities of the marks must be assessed by reference to the overall impressions created by the marks bearing in mind their distinctive and dominant components. Each mark must be viewed as a whole and should not be dissected for the purposes of comparison. This is because the average consumer normally perceives marks as a whole and does not proceed to analyse its various details.

(iv) The higher the degree of distinctiveness of the registered trade mark the greater the protection granted to it and vice versa. Distinctiveness may be inherent or enhanced by a reputation which the mark enjoys on the market".

\section{'Category of good or services'}

In assessing degree of similarity, account must be taken of the category of goods or services of the marks. In this case, the products of Nualtra under the NUTRIPLEN mark (and which Nualtra refused to undertake not to sell) were oral nutritional supplements. Although these products are not prescription only products, they are only available to consumers under medical supervision (over the counter dispensing and not on aisle display). This fact was relevant in considering the public which might be confused by the mark similarity. ${ }^{10}$

\section{NUTRIPLEN goods similar to NUTRITPLETE goods?}

Article 9(2)(b) requires that the goods which bore the NUTRIPLEN mark be identical or similar to the goods for which NUTRITPLETE is registered in order for Aymes to succeed. The Article states

"the sign is identical with, or similar to, the EU trade mark and is used in relation to goods or services which are identical with, or similar to, the goods or services for which the EU trade mark is registered". ${ }^{11}$

NUTRIPLETE is registered in Class 5 (and Class 32), which includes nutritional supplements for medical use. The NUTRIPLEN products were in fact oral nutritional supplements which were sold under medical supervision. Nualtra sought to register NUTRIPLEN as a CTM in Class 5 (and Class 32). For the purposes of Article 9, the court felt that there is little doubt that the NUTRIPLEN goods are similar to the goods for which NUTRIPLETE is registered. ${ }^{12}$

\section{Infringement if no goods sold under NUTRIPLETE mark}

Neither Aymes nor Nutrimedical sold products under the NUTRIPLETE brand. This was because Aymes did not want to invest in a product launch when NUTRIPLEN was on the market and also because Nualtra would not give undertakings not to use the NUTRIPLEN brand in future. ${ }^{13}$

While NUTRIPLETE was registered for goods including oral nutritional supplements (Class 5), no such goods were sold. The OHIM decision, referring to "likelihood of confusion on the part of the public" states

"A likelihood of confusion exists if there is a risk that the public might believe that the goods or services in question, under the assumption that they bear the marks in question [emphasis added], come from the same undertaking or, as the case may be, from economically linked undertakings". ${ }^{14}$

The court notes that while the OHIM statement was about likelihood of confusion in the context of the registration of a trade mark under Article 8(1)(b), the same concept ("likelihood of confusion")

Nutrimedical B.V. and by order Aymes International Limited v Nualtra Limited, parag 22. Nutrimedical B.V. and by order Aymes International Limited v Nualtra Limited, parag 24. Nutrimedical B.V. and by order Aymes International Limited v Nualtra Limited, parag 25. Nutrimedical B.V. and by order Aymes International Limited v Nualtra Limited, parag 26. Nutrimedical B.V. and by order Aymes International Limited v Nualtra Limited, parag 27. OHIM decision, 20th August, 2014, p 73. Referred to in Nutrimedical B.V. and by order Aymes International Limited $v$ Nualtra Limited, parag 28. 
applies in Article 9(1)(b) in relation to the right to prevent the owner of a mark which is confusingly similar from being used in the course of trade. The use of this assumption, that the goods are available under the marks in question (whether in a trade mark application situation or a trade mark infringement situation), is premised on the principle that a trade mark can be infringed, even if the owner of the trade mark has not yet traded under that trade mark. ${ }^{15}$

While the foregoing statement was made by OHIM, which is not a court and is therefore not binding on this Court, it reflects a principle which has been accepted by the courts. This is clear from the decision of the English High Court in Origins Natural Resources $v$ Origin ${ }^{16}$ in relation to infringement under s.10 of the UK Trade Marks Act 1994. This Act, like its Irish equivalent (Trade Marks Act 1996), fulfilled UK obligations under EU trade mark law in relation to CTMs. The wording of s.10(2) of the UK legislation (as set out below) is almost identical to the wording of Article 9(2)(b) of the ETMR (which as previously noted is the relevant legislation in this case), and at pg 284 of his judgment, Jacob J. in Origins stated that

"The defendants say that they have a number of defences. It is convenient to run through those in turn. First, they say that I should look at the question of infringement, because the main question before me is one for the future, under the provisions of s.10(2) of the [TMA]. This provides

'A person infringes a registered trade mark if he uses in the course of trade a sign where, because the sign is similar to the trade mark and is used in relation to goods or services identical with or similar to those in which the trade mark is registered, there exists a likelihood of confusion on the part of the public which includes the likelihood of association with the trade mark". ${ }^{17}$

The defendant suggested "how can there ever be a likelihood of confusion on the part of the public?" The Judge felt this point was "misconceived." Section 10 of the Trade Marks Act 1994, he said, "requires the court to assume the mark of the plaintiff is used in a normal and fair manner in relation to the goods for which it is registered and then to assess the likelihood of confusion and deception in relation to the way in which the defendant uses the mark, discounting external added matter or circumstances. The comparison is mark for mark."

In determining breach of rights, the court is required to assume that NUTRIPLETE is used in a normal and fair manner in relation to the goods registered, which includes nutritional supplements for medical use "and so nothing turns on the fact that the Aymes has not to date sold any ONS products under the NUTRIPLETE trade mark". ${ }^{18}$

The defendant goods sold (under NUTRIPLEN) and plaintiffs goods (which might be sold under the NUTRIPLETE) are identical since NUTRIPLETE is registered in the Class which includes ONS. "[I]t is irrelevant that the owner of that trade mark has not sold any products under that trade mark. What is relevant is that Nualtra sold ONS products under an allegedly confusingly similar mark and that company is not willing to give an undertaking to not do so again in the future". ${ }^{19}$

\section{Meaning 'on the part of the public'}

The products sold under NUTRIPLEN were ONS products, and required to be sold under medical supervision in the EU. These products are designed for people who are malnourished and have

\footnotetext{
$15 \quad$ Nutrimedical B.V. and by order Aymes International Limited v Nualtra Limited, parag 29.

$16 \quad$ Origins Natural Resources v Origin [1995] FSR 280.

$17 \quad$ Nutrimedical B.V. and by order Aymes International Limited v Nualtra Limited, parag 30.

$18 \quad$ Nutrimedical B.V. and by order Aymes International Limited v Nualtra Limited, parag 31.

$19 \quad$ Nutrimedical B.V. and by order Aymes International Limited v Nualtra Limited, parag 32.
} 
specific nutritional needs, e.g. to aid recovery from serious illnesses or wounds. This means that the products are prescribed or are sold over the counter without prescription but by a pharmacist. ${ }^{20}$

The court considered the meaning of the term "public" in the analysis of whether that public is likely to be confused. Alcon $v$ OHIM ${ }^{21}$ (ECJ/CJEU) concerned whether the mark TRAVATAN could be registered as a CTM for ophthalmic pharmaceutical products in light of the earlier registration of TRIVISTAN for pharmaceutical, veterinary and hygiene products. Unlike the present case, the products in the Alcon case were medicinal products which were only available on prescription by a doctor and could not be purchased by a member of the public from a retail pharmacy. The Court of First Instance (CFI) held that the relevant public was composed not only of end users, but also professionals (doctors who prescribe the medicinal product and pharmacists who sell that prescribed product). The CFI rejected the registration of TRAVATAN as confusingly similar to TRIVISTAN. The applicant appealed unsuccessfully. ${ }^{22}$

It is clear from this case that where a product is sold on prescription only, it is nonetheless the case that the relevant public for the purposes of determining whether there is a likelihood of confusion, is made up of, not only healthcare professionals who prescribe the product, but also the end-users. In the case before this Court, the ONS products are not prescription only, but rather over the counter products. This means that even if the ONS products were sold only on prescription, which they are not, the relevant public would still be made up of, not only healthcare professionals but also the endusers, since as is clear from the Alcon case, account must be taken of the ability of the end users of ONS products to ensure that the healthcare professionals take their preferences for certain branded products into account. ${ }^{23}$

The case was seen as even stronger in this case, for the relevant public being made up of end users, as well as healthcare professionals, because, unlike in the Alcon case where the products were only available on prescription, ONS products are available without a prescription. Eventhough only a small percentage of ONS products sold by Nualtra were sold without prescription, given this fact, the role of the end user in the relevant public is greater, albeit marginally greater, in the situation before the Court than that in a situation where the products are only available on prescription, as in the Alcon case. $^{24}$

Therefore, the Court had "little hesitation in relying on the Alcon case to reach its conclusion that the relevant public in the present case is made up of end-users of the ONS products as well as healthcare professionals". 25

\section{Ability of end users to influence healthcare professionals}

The Alcon case makes clear that, even prescription only medications (not selected by the user but by the healthcare professional), there could still be a likelihood of confusion on the part of the end user. As noted by the ECJ/CJEU, end users have the ability to make those healthcare professionals take into account their perception of the trade marks and their requirements or preferences. The ECJ/CJEU held that confusion in the mind of the end user as between two different products might result in the wrong product being prescribed or dispensed by the healthcare professional eventhough the dispensing pharmacist exercised due care. ${ }^{26}$

\section{Visual, aural and conceptual similarity}

Nutrimedical B.V. and by order Aymes International Limited v Nualtra Limited, parag 33. Alcon v OHIM [2007] ECR I-03569.

Nutrimedical B.V. and by order Aymes International Limited v Nualtra Limited, parag 34. Nutrimedical B.V. and by order Aymes International Limited v Nualtra Limited, parag 35. Nutrimedical B.V. and by order Aymes International Limited v Nualtra Limited, parag 36. Nutrimedical B.V. and by order Aymes International Limited v Nualtra Limited, parag 37. Nutrimedical B.V. and by order Aymes International Limited v Nualtra Limited, parag 38. 
As is clear from Cofresco, ${ }^{27}$ the court must consider if there is a risk that the public, made up of end users, as well as healthcare professionals, would believe that NUTRIPLEN products are from the NUTRIPLETE trade mark undertaking in light of the alleged visual, aural and conceptual similarity of the marks, based on the overall impression which the marks create.

Taking these in turn

“a) Visual similarity

The only difference between the two signs NUTRIPLEN and NUTRIPLETE is at the end of the signs, namely an ' $\mathrm{N}$ ' ending versus a 'TE' ending. Save for this difference, the two signs are visually identical, since one is a nine letter word and the other is a ten letter word, but significantly they share the first eight letters 'NUTRIPLE'. In this regard, it is relevant to note the judgment of Smyth J. in Unilever plc v Controller of Patents [2007] ILRM 389 at 397 that:

'Whether two words are used or a compound word is used, if the emphasis is clearly on the first word or prefix in the compound then it seems to me that that is the predominant sound and visual impact of the mark'.

In that case, the High Court held that there was a risk of confusion between the registered trade mark 'Sun' and the mark 'SunSmile', because, inter alia, the first three letters (out of eight) in the offending mark were identical to the registered trade mark 'Sun' which was part of a family of trade marks, which included Sunlight, Sun System, Sun Tablets, Sun Detergents, Sun Salt and Sun Rise Aid.

In the case before this Court, it is relevant to note that;

- $\quad$ eight letters (out of nine) in the alleged offending mark (NURTIPLE/N are the same, and in the same order, as the eight letters (out of ten) in the registered trade mark (NUTRIPLE/TE);

- these are the first eight letters, which as noted by Smyth J. in the Unilever case, is more significant than later letters;

- the shared root is 'NUTRIPLE' and the alleged offending mark, NUTRIPLEN has only one additional letter more than the shared root (i.e. $\mathrm{N}$ ) and the registered trade mark, NUTRIPLETE, has only two additional letters more than the shared root (i.e. TE).

On this basis, it seems clear to this Court that under the visual similarity heading, the two signs are very similar.

b) Aural similarity

As with visual similarity, it is relevant to note that the two marks contain the same root (NUTRIPLE) and in the case of NUTRIPLEN, it only has one letter (N) after the shared root and, in the case of NUTRIPLETE it has only two additional letters (TE) after this root. If one analyses the two marks as syllables, they would be divided as follows NU/TRI/PLEN versus NU/TRI/PLETE and one can observe that the first two syllables are identical. As regards the third syllable in these two three syllable marks, it can be observed that this would have to be different, since otherwise the marks would in fact be identical. While the third syllables are therefore, of necessity different, they are nonetheless similar in pronunciation in the English language; PLEN versus PLETE. Indeed, since this aural difference is at the end of the two marks, it is of less significance in distinguishing the marks and avoiding confusion, than if it was at the start or middle of the marks. This is clear from the statement of Smyth J. above in the Unilever case regarding compound words, which statement, by its express terms, is applicable 
not only to the visual impact of the marks, but also to the aural impact of the marks, since consumers of products tend to pronounce more significantly the first few syllables.

It is also relevant that the NUTRIPLETE mark is registered as an EU trade mark, and so in hearing this application for relief based on an alleged infringement of an EU trade mark, this Court is exercising its jurisdiction as the EU trade mark Court of First Instance. In this respect, evidence was provided to the Court that the two marks are in fact aurally identical in the French language, which is used in three European countries (France, Belgium and Luxembourg), as the last syllable/letters of a word in French are generally not pronounced.

For the foregoing reasons, this Court concludes that the two marks are aurally very similar and indeed in at least one EU language, the marks are aurally identical.

c) Conceptual similarity

The issue of conceptual similarity raises the question of whether the words that constitute the two competing signs would be regarded as having similar meanings. Neither NUTRIPLEN nor NUTRIPLETE has any meaning in English, nor was any evidence adduced to the Court regarding a meaning in any other European language. Both marks share the prefix 'nutri', which is associated with the word nutrition and in English, at least, there is likely, in this Court's view, to be some connection between both two marks and the concept of nutrition. Accordingly, as regards conceptual similarity between the two marks, while there is some similarity between the apparent meaning of the two words which make up the two marks, in the sense that they are both associated with nutrition, it is a limited similarity, since the two words themselves have no particular meaning.

On this basis, this Court concludes that there is some, but limited, conceptual similarity between the two marks."

\section{Likelihood of confusion between the marks}

After considered the two marks under the three headings of visual, aural and conceptual similarity, the court concluded that the two marks are very similar visually, very similar aurally and that there is a limited conceptual similarity between them. The marks cover identical goods in the form of ONS products, albeit that the plaintiffs have not marketed any goods under the name NUTRIPLETE and the defendant has re-branded its ONS products. ${ }^{28}$

As ONS are products consumed under medical supervision, consumers are likely to have a highdegree of attentiveness to the products. As noted in Alcon, such persons are reasonably well-informed, reasonably observant and circumspect. These products are not on pharmacy aisle display for endusers. However, as there is a very high degree of similarity between marks, the Court was of the view that, despite high consumer attentiveness, and assuming that ONS products are being sold under the competing marks, there is a likelihood of confusion in the eyes of end users, such that an end user may regard ONS products under NUTRIPLEN as coming from the same undertaking as NUTRIPLETE. ${ }^{29}$

\section{Injunction}

The Court concluded that Aymes was entitled to the injunction sought, pursuant to Articles 9 and 102 of the ETMR, preventing Nualtra from using, in the course of trade in dietetic food and substances adapted for medical use, the mark NUTRIPLEN.

The court noted that Nualtra had rebranded but refused to give an undertaking. 
"Thus, Nualtra was refusing to give an undertaking and thereby willing to defend its right to use NUTRIPLEN, at a cost of $€ 1.3$ million in legal fees, even though it had no intention of using that mark. The only conclusion which this Court can draw from this evidence is that Nualtra was contesting, at enormous expense, the injunction on a point of principle, rather than for commercial reasons."

"This decision by Nualtra to defend, at such expense, its right to use a trademark, which it was not going to use, is rendered even more curious when one considers that to be successful in that defence, Nualtra needed the High Court to find that NUTRIPLEN was not confusingly similar with NUTRIPLETE, even though there had been decisions by two European Trade Mark bodies (OHIM and the Board of Appeal) that these marks were in fact confusingly similar. Thus, Nualtra spent $€ 1.3$ million fighting a case, which could not have been regarded as foregone conclusion (if for no other reason than there had been two negative EU decisions on the issue) and it was doing so on a point of principle."

\section{Damages}

There was no evidence of actual loss. The plaintiff provided expert valuation evidence of a hypothetical licence fee, estimated at $€ 260,000$ from 2012 to 2016, the period of use of the NUTRIPLEN mark.

The Court refused an account of profits, and granted infringement damages. No profits were earned by Nualtra. "[A]s an account of profits is an equitable remedy, this Court finds the conduct of Aymes in issuing the poison pen letter and the fake NHS email is so far from the 'clean hands' that are required when seeking equitable relief, that this Court believes that it would be appropriate to refuse to grant the plaintiffs this equitable relief." While Nualtra breached the trade mark, the court said that it should not have to incur legal costs, other than such costs as are absolutely necessary, in relation to that infringement.

The court also commented on the issues of damages, legal costs and even referred to changes have been proposed in England \& Wales, by Lord Justice Jackson in the Review of Civil Litigation Costs: Final Report. ${ }^{30}$

The Court refused to permit such an election to seek an account of profits.

While the plaintiff sought to refer to the valuation of a notional trade mark licence fee of $€ 260,000$, the comparators and what was and was not being licensed did not directly compare.

The Court took into account the fact that the trade mark was assigned "at arms length" in June 2015 for $£ 50,000$ (the equivalent of $€ 69,640$ at that time). This right was assigned in perpetuity and not for period of 3.5 years, which is the period which the Court must asses. ${ }^{31}$

The Court held that the true value of the licence of NUTRIPLETE for a period of 3.5 years and thus the damages which should be awarded was the sum of $€ 35,000$, and not the notional licence fee of $€ 260,000$.

Practitioner will note, therefore, that an earlier assignment fee may have relevance in at a later date in the context of a legitimate infringement action. The lower the assignment sale fee, the potential arises for lower damages than might otherwise have been anticipated.

$30 \quad$ See also Tracey $v$ Burton [2016] IESC 16, parag 45, each of which were referred to.

31 However, on the other hand Nutramedical obtained a royalty-free licence under the terms of that assignment, to use the trade mark outside the UK, Ireland and France with the consent of Aymes which could not be unreasonably withheld. 
In the context of intra group assignments, and which may entail lower than at arms length assignment transaction fees, it remains to be seen if this would be discounted as a factor in order to avoid the possibility of damages which might otherwise arise in an infringement case being reduced.

Dr Paul Lambert adjunct lecturer, consultant (lex@mydistillex.com) is the author of International Handbook of Social Media Laws; Gringras: The Laws of the Internet (fourth edition); A User's Guide to Data Protection (second edition); The Data Protection Officer: Profession, Rules and Role (2017); and various publications on intellectual property and data protection. 